\title{
Morbidity and mortality due to surgical congenital malformations from the perspective of surgical neonatal ICU outside a maternity service: a retrospective cohort study
}

\author{
DSofia Oliva-Costa \\ (D) Samir Nahass² \\ (iD)Andréa Dourado \\ (iD) Selma Lopes ${ }^{1,4}$
}

\begin{abstract}
1. Faculdade de Medicina da Bahia, Universidade Federal da Bahia (UFBA), Salvador, BA, Brasil. 2. Coordenador médico UTIN cirúrgica HMG; Hospital Martagão Gesteira (HMG), Salvador, BA, Brasil. 3. Enfermeria líder UTIN cirúrgica HMG; Hospital Martagão Gesteira (HMG), Salvador, BA, Brasil. 4. Médica da UTIN cirúrgica; Hospital Martagão Gesteira (HMG), Salvador, BA, Brasil.
\end{abstract}

http://dx.doi.org/10.1590/1806-9282.66.9.1252

\section{SUMMARY}

OBJECTIVE: To describe the characteristics of patients treated at a level III surgical Neonatal Intensive Care Unit outside of a maternity service and analyze possible risk factors for mortality in this population.

METHODS: A retrospective cohort study evaluating patients admitted to a level III surgical Neonatal Intensive Care Unit from June/2015 to November/2017. Univariate analysis was performed by the Chi-square test and T-student test or Mann-Whitney test. Multivariate analysis by logistic regression was performed including in the model the variables with a $P$-value $<0.2$ in univariate analysis. KaplanMeier curve and Log-Rank test were performed using the variables that were statistically associated with death in the multivariate analysis. A significance level of $a=5 \%$ and an error $B=80 \%$ were adopted.

RESULTS: During this period, 246 patients were admitted to this service. 58 (23.8\%) patients died, with a mean time until death of 18 days. Half of the patients had a clinical diagnosis of sepsis (50.6\%), blood culture was positive in $25.2 \%$, and gram-positive bacteria $(48.4 \%)$ were the main pathogens isolated. The variables that remained in the final model after multivariate analysis were diagnosis of congenital heart disease $(O R=4.5 ; p=0.016)$, clinical diagnosis of sepsis $(O R=8.1 ; p=0.000)$, and isolation of gram-positive bacteria in blood culture $(O R=3.9 ; p=0.006)$.

CONCLUSION: The level III surgical Neonatal Intensive Care Unit outside of a maternity service has a different profile of morbidity and mortality, and death was associated with the diagnosis of congenital heart disease, the clinical diagnosis of sepsis, and the isolation of gram-positive bacteria in the blood culture

KEYWORDS: Infant mortality. Congenital abnormalities/surgery. Intensive care units, neonatal.

\section{INTRODUCTION}

Currently, neonatal deaths account for more than half of infant mortality in Brasil, and early neonatal death (in up to 7 days) is its main component, indicating a close relationship between prenatal care and delivery assistance. ${ }^{1}$ Maternal and perinatal factors, such as prematurity and perinatal infections, 
are the main causes of death in the neonatal period, followed by congenital malformations, which together account for $80 \%$ of deaths during the $1^{\text {st }}$ year of life. ${ }^{1}$ However, when infant mortality is considered as a whole, the deaths due to congenital malformations have surpassed the perinatal causes in recent years, being consolidated as the main cause of death in the first year of life. This is due to the growth in mortality due to this cause, which rose from $11.4 \%$ in 2000 to $20.7 \%$ in $2013 .^{1}$ One explanation for that could be the improvement of health care service quality, resulting in the maintenance of life in the early neonatal phase due to better access and quality of service in Neonatal Intensive Care Units (NICU), which in turn enables higher rates of diagnostic and notification of these malformations. ${ }^{2}$

Congenital malformations are morphogenetic changes capable of causing functional changes, with a global prevalence of $2-3 \%{ }^{3}$ The impact of congenital malformations on infant mortality depends on several factors, including the effectiveness of primary prevention that the prevalence of anomalies, and, above all, the access to, availability and quality of health care services for medical and surgical treatment to preserve life. ${ }^{4}$

The last census of the Brazilian Association of Intensive Medicine (AMIB) in 2016 showed that the number of NICUs represents $24.2 \%$ of all ICU services in the country ${ }^{5}$. The number of beds in Bahia represents $21.7 \%$ of the Northeast, and $13.5 \%$ of them are located in the capital. NICUs outside maternity services are infrequent in Brasil since they usually are located in general hospitals with maternity services. Souza et al. ${ }^{6}$ demonstrated that $82.4 \%$ of the services of NICU/PICU were located in general hospitals, in a study conducted in 2002 in the city of São Paulo. This distribution of services is logical, considering that out of the total number of deaths in the $1^{\text {st }}$ year of life, $7.1 \%$ occur in the first hour of life, and $24.7 \%$ in the first day of life, demonstrating the importance of services located where it is possible to have immediate access so as to act during the most critical period for mortality. ${ }^{1}$

The Surgical NICU of the Martagão Gesteira Hospital was inaugurated in 2015 as a level III NICU and was consolidated as a reference service for the entire state of Bahia. It services mainly newborns with congenital defects that require a surgical NICU to undergo a surgical procedure to preserve life at this stage. This service is located in a pediatric hospital outside a maternity service; thus, the assistance presents some limitations due to the need for transport for other services and suffers from a lack of important information for patient care, such as reliable documentation of prenatal care and data relating to the labor conditions. Thus, we couldn't find in the literature any studies performed at a service that presents a parallel with the characteristics mentioned above.

Therefore, this study is justified because it is an analysis of a level III surgical NICU service outside a maternity service, which is an unusual service model, which is a reference for the entire state of Bahia, servicing a extensive geographic area of great importance in the Northeast of the country, a region that still lacks studies when compared to large centers of the South, and Southeast regions and that represents the highest rate of neonatal deaths in the country (38.3\%). ${ }^{7}$ Thus, the goal of this study was to establish the epidemiological profile of patients treated in this service and analyze which factors were more closely related to neonatal mortality to improve the planning of preventive health care for this population.

\section{METHODS}

This is a retrospective cohort study carried out with all the children admitted to the NICU of the Martagão Gesteira Hospital, a reference level III neonatal surgical ICU for surgical congenital malformations in the state of Bahia.

The inclusion criteria were all children admitted to the NICU of the Martagão Gesteira Hospital from June/2015 to November/2017.

The data were collected by reviewing the electronic medical records, relying on information from patient admission to discharge or death.

The independent variables analyzed were: sex, prematurity, low birth weight, days of life upon admission, days of hospitalization, diagnosis at admission, presence of congenital malformation, having undergone surgery, clinical diagnosis of sepsis, blood culture results. The dependent variable considered was death.

The congenital malformations were classified according to the following categories: Malformations of the gastrointestinal tract (GIT), clinical diagnoses, malformations of the central nervous system (CNS), congenital heart defects and others (wall closing defects, urinary tract malformations, and tumors). The patients were classified according to birthweight 
as low weight $(<2500 \mathrm{~g})$ and gestational age in preterm infants ( $<37$ weeks). The pathogens isolated in blood cultures were classified as gram-positive bacteria, gram-negative bacteria, and fungus.

The statistical analysis was performed using the data analysis software Statistical Package for Social Sciences, V 23.0 (SPSS Inc., Chicago, IL, USA). We used the Kolmogorov-Smirnov test to determine the normality of the distribution of continuous variables. For the descriptive analysis, we used means and standard deviation for continuous variables with normal distribution, median and interquartile ranges for continuous variables with non-normal distribution, and proportions for categorical variables. We calculated the odds ratio and confidence interval (95\% CI) for all the variables. Univariate analysis was conducted comparing the individuals based on the death outcome using the chi-square test was used for the categorical variables and the Student t-test or Mann-Whitney test for continuous variables, depending on their distribution. Then we carried out a multivariate analysis by logistic regression, including variables that showed a p-value $<0.2$ in the univariate analysis. Survival analysis was performed by the Kaplan-Meier curve and Log-Rank test with the variables that were statistically associated with death in the multivariate analysis. We adopted a significance level of $\mathrm{a}=5 \%$ and an error $\mathrm{B}=80 \%$.

This study was carried out after approval by the Research Ethics Committee of the Faculty of Medicine of Bahia CAEE (66804316.3.0000.5577).

\section{RESULTS}

During this period, 246 patients were admitted to this service and had their data collected. Of these, most were male, the minority was premature (39.0\%), and nearly half had low birth weight (46.6\%). The median of days of life on admission was 9 days, which classified the population as late neonates. The vast majority of hospitalized patients had some congenital malformation (77\%). The main congenital malformations were: Malformations of the GIT (32\%), malformations of the CNS (18.4), and congenital heart diseases (10.7\%). (TABLE 1)

Most patients underwent some surgical procedure $(67.4 \%)$ to correct the congenital malformation. The clinical diagnosis of sepsis was present in little more than half of the cases (50.6\%). The blood culture was positive in only $25.2 \%$; and the main pathogens isolated were Gram-positive bacteria (48.4\%), mainly Coagulase-negative Staphylococcus, representing almost half of all isolated pathogens (43.5\%), followed by gram-negative bacteria (37.1\%), mainly Klebsiella sp. (16.1\% of all pathogens isolated), and fungi $14.5 \%$, with only Candida sp being isolated. The mean length of hospitalization was 13 days. Death was the outcome in $23.8 \%$ of the cases, with a median of 18 days up to this outcome. (TABLE 2)

It was possible to demonstrate through univariate analysis that the variables that were associated with death were low birth weight, diagnosis at admission, diagnosis of sepsis, and blood culture results. The variables that presented a trend of significance

TABLE 1. PATIENT DISTRIBUTION BY EPIDEMIOLOGICAL CHARACTERISTICS. SALVADOR (BA) BRASIL, 2018

\begin{tabular}{|c|c|c|c|c|}
\hline & $\begin{array}{l}\text { Patients } \\
\mathrm{N}=246(\%)\end{array}$ & $\begin{array}{l}\text { Death } \\
\mathrm{N}=58(23.8 \%)\end{array}$ & Gross OR $(95 \% \mathrm{Cl})$ & P-value \\
\hline Sex & & & $1.21(0.673-2.191)$ & 0.519 \\
\hline Male & $133(54.1 \%)$ & $29(22.1 \%)$ & & \\
\hline Female & $113(45.9 \%)$ & $29(25.7 \%)$ & & \\
\hline Prematurity & $87(39 \%)$ & $22(25.3 \%)$ & $1.195(0.634-2.254)$ & 0.719 \\
\hline Low birth weight & $109(46.6 \%)$ & $32(29.4 \%)$ & $1.946(1.049-3.609)$ & 0.033 \\
\hline Days of life at admission (median; IQR) & $9 ; 22$ & $119.66^{1}$ & - & 0.771 \\
\hline Days of hospitalization (median; IQR) & $13 ; 22$ & $136.0^{1}$ & - & 0.082 \\
\hline Congenital malformation & $188(77 \%)$ & $46(24.7 \%)$ & $1.205(0.586-2.475)$ & 0.612 \\
\hline Diagnosis at admission & & & & 0.002 \\
\hline Clinical diagnosis ${ }^{*}$ & $56(23 \%)$ & $12(21.4 \%)$ & 1.0 & - \\
\hline GIT Malformation & $78(32 \%)$ & $20(25.6 \%)$ & $1.264(0.559-2.859)$ & 0.573 \\
\hline CNS Malformation & $45(18.4 \%)$ & $6(13.6 \%)$ & $0.579(0.198-1.691)$ & 0.318 \\
\hline Congenital heart disease & $26(10.7 \%)$ & $14(53.8 \%)$ & $4.278(1.572-11.639)$ & 0.004 \\
\hline Other malformations & $26(10.7 \%)$ & $6(24 \%)$ & $0.688(0.233-2.026)$ & 0.497 \\
\hline
\end{tabular}

${ }^{1}$ Sum of the Mann-Whitney test rank; *Variable used as reference 
TABLE 2. PATIENT DISTRIBUTION BY THE CLINICAL CHARACTERISTICS OF EVOLUTION DURING HOSPITALIZATION. SALVADOR (BA) BRASIL.

\begin{tabular}{l|l|l|l|l} 
& Patients N=246(\%) & Death 58 (23.8\%) & Gross OR (IC 95\%) & P-value \\
\hline Surgery & $164(67.2 \%)$ & $44(24 \%)$ & $8.758(0.897-3.444)$ & 0.098 \\
\hline Diagnosis of sepsis & $118(50.6 \%)$ & $46(39.3 \%)$ & 1.0 & 0.000 \\
\hline Blood culture & & & $4.353(1.942-9.755)$ \\
\hline Negative & $182(74.5 \%)$ & $34(18.7 \%)$ & $15(50 \%)$ & $2.322(0.911-5.917)$ \\
\hline Gram-positive & $30(48.4 \%)$ & $8(34.8 \%)$ & $0.544(0.066-4.497)$ & 0.000 \\
\hline Gram-negative & $23(37.1 \%)$ & $1(11.1 \%)$ & 0.078 & 0.572 \\
\hline
\end{tabular}

* Variable category used as reference

with a p-value $<0.2$ were days of hospitalization, having undergone surgery. All of these variables were included in the multivariate analysis by logistic regression.

After the completion of the multivariate analysis, it was possible to observe that the only three variables in the model that still demonstrated a significant association with death were the diagnosis of congenital cardiopathy, which resulted in a chance approximately 4.5 times greater of death, the clinical diagnosis of sepsis, with a 8.1 times higher chance of death, and the presence of gram-positive bacteria isolated in the blood culture, with a 3.9 times higher chance of death. (TABLE 3).

The survival curve was drawn with the three variables that remained in the model after multivariate analysis. The median of days until death for the entire population was 18 days (95\% CI 11.7-24.2). The clinical

TABLE 3. RESULTS OF THE LOGISTIC REGRESSION FOR RELATED VARIABLES AND MORBIDITY AND MORTALITY IN PATIENTS FROM THE SURGICAL NICU. SALVADOR (BA) BRASIL, 2018.

\begin{tabular}{c|l|l} 
& Adjusted OR (95\% CI) & P-value \\
\hline Diagnosis at admission & & \\
\hline \multicolumn{1}{c|}{ Clinical diagnosis* } & 1.0 & - \\
\hline GIT Malformation & $0.925(0.317-2.699)$ & 0.389 \\
\hline CNS Malformation & $0.557(0.147-2.108)$ & 0.557 \\
\hline Congenital heart disease & $4.5(1.317-15.432)$ & 0.016 \\
\hline Other malformations & $0.656(0.170-2.533)$ & 0.540 \\
\hline Days of hospitalization & $0.979(0.956-1.003)$ & 0.084 \\
\hline Surgery & $2.531(0.976-6.564)$ & 0.056 \\
\hline Diagnosis of sepsis & $8.121(3.332-19.795)$ & 0.000 \\
\hline Blood culture & & \\
\hline Negative* & 1.0 & - \\
\hline Gram-positive & $3.958(1.490-10.513)$ & 0.006 \\
\hline Gram-negative & $1.622(0.546-4.817)$ & 0.384 \\
\hline Fungus & $0.395(0.043-3.583)$ & 0.409 \\
\hline
\end{tabular}

* Variable category used as reference diagnosis of sepsis was the only variable that showed statistical difference regarding the number of days until death between the groups in the Log-Rank test, showing that individuals who presented sepsis had a median of 18 days until death (95\% CI 11.3-24.6), while those who did not have a clinical diagnosis of sepsis had a median of 13 days (95\% CI 0.0-38.6), with a p-value $=0.005$ in the Log-Rank test (FIGURE 1).

\section{DISCUSSION}

The NICU services not linked to a maternity service usually present different epidemiological profiles and morbidity and mortality characteristics. We can observe that the profile of the patients treated in this service was of neonates with low birth weight, the minority of which was premature (39\%), admitted already in the late neonatal period, in their great majority with surgical congenital malformations.

FIGURE 1. SURVIVAL CURVE OF INDIVIDUALS WITH A DIAGNOSIS OF SEPSIS.

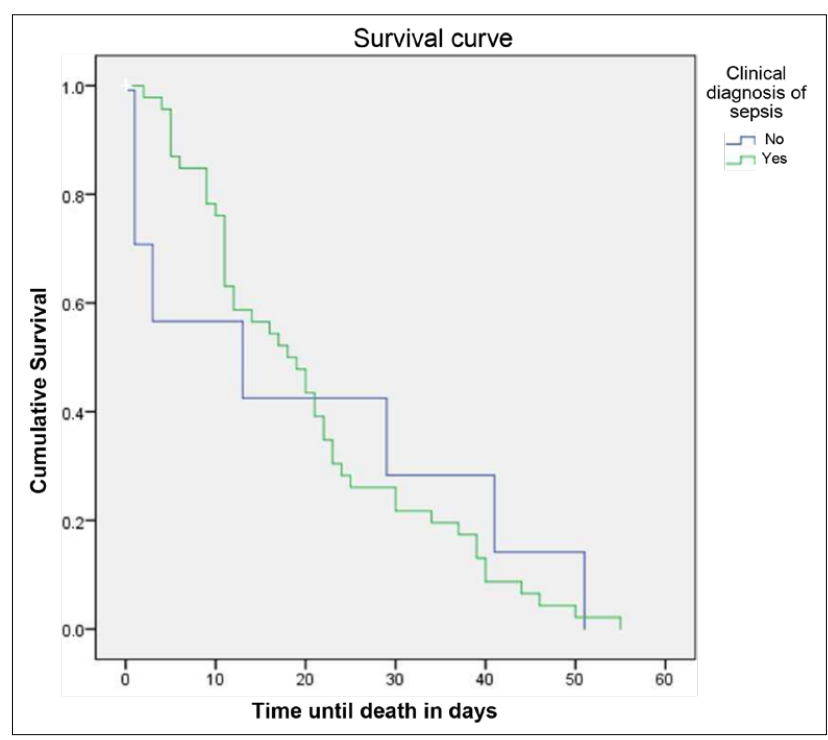


These characteristics alone imply a different pattern of morbidity and mortality in this period since maternal and perinatal factors are expected to already have less impact on mortality. ${ }^{1}$

Initially, low birth weight was one of the variables associated with death in the univariate analysis. This finding was already expected since this association is well established in the literature. ${ }^{7-9}$ However, in the multivariate analysis, low birth weight was not associated with death, so that it is assumed that, when there is interaction with other factors, perinatal factors demonstrate a lower influence in the late neonatal period in detriment to factors related to hospitalization and the underlying disease.

GIT malformations were the most frequent diagnosis in our population, along with malformations of the CNS, and congenital heart diseases. Whereas the diagnosis of congenital heart disease was the only one associated with death in the univariate analysis and that remained in the final model after the multivariate analysis, presenting a 4.5 times higher chance of death, as corroborated by Stewart et al. ${ }^{10}$ That demonstrates that congenital malformations are responsible for $45 \%$ of deaths in a NICU in North America, and congenital heart disease is one of the main contributing factors. In addition, this diagnosis in our population showed a high frequency in comparison to the general population, in which the prevalence is approximately 4 to 5 cases per 1000 live births. ${ }^{11}$ This greater frequency can be due potentially to the high severity of heart malformations, requiring the assistance of highly specialized services, something that is corroborated by the high mortality rate (53.8\%), and this is the diagnosis with the highest rate of lethality in our population.

The univariate analysis failed to demonstrate an association between the diagnosis of congenital malformation and death, as would be expected for the late neonatal period, something that has been demonstrated in several studies on general NICU services. ${ }^{8,10,12}$ However, our sample consists of patients from a NICU service that receives mainly surgical patients; thus, almost our entire population has been diagnosed with some type of malformation, which leads to the failure in identifying a difference between the groups.

The clinical diagnosis of sepsis was established in almost half of the individuals in our population and proved to be associated with death in the univariate analysis, remaining in the model after multivariate analysis and increasing the chance of death in around 8 times. However, this was not reflected by positive blood culture results, although this was already expected since it is known that the positivity rate of blood cultures from neonates is usually low, often due to the collection of an insufficient volume of blood, both due to difficulty in puncture and unfavorable hemodynamic conditions of these patients. ${ }^{13}$ The pathogens most frequently isolated were similar to those demonstrated in the literature, indicating a higher frequency of agents that usually are not pathogenic in healthy newborns, such as coagulase-negative Staphylococcus and Candida sp. ${ }^{14,15}$ In fact, even after the multivariate analysis, the isolation of gram-positive bacteria, among them the most frequent being coagulase-negative Staphylococcus, increased the chance of death in approximately 4 times. In North America, infections by this pathogen are responsible for up to $70 \%$ of the cases of neonatal sepsis and are related to longer hospitalizations and, consequently, higher treatment costs, thus burdening the health system. ${ }^{16}$

The survival analyses were carried out with the three variables that remained in the model after multivariate analysis. However, the clinical diagnosis of sepsis was the only variable to present a statistical difference regarding the number of days until death between the groups, demonstrating that the individuals who received a clinical diagnosis of sepsis later died, suggesting that the longer the length of hospitalization, the greater the chance of nosocomial sepsis due to interventions carried out.

Among the limitations of our study, we emphasize that the main one was analyzing a single-center, with retrospective data collection from patient records, which presents a risk of record bias.

\section{CONCLUSION}

We conclude that the NICU service outside a maternity service has a different profile of morbidity and mortality, receiving mainly patients with congenital malformations that require surgical repair, and death as an outcome was associated with the diagnosis of congenital heart disease, clinical diagnosis of nosocomial sepsis, and isolation of gram-positive bacteria in the blood culture.

\section{Funding source}

Student scholarship provided by FAPESB/PIBIC. 


\section{Author's Contribution}

Sofia Oliva-Costa - study design; acquisition, analysis, and interpretation of data; drafting of the manuscript; Samir Nahass - acquisition of data; review and critical analysis of the manuscript; approval of the final version for publication; Andréa Dourado
- acquisition of data; review and critical analysis of the manuscript; approval of the final version for publication; Selma Lopes - project concept; design of the study; acquisition, analysis, and interpretation of data; critical review of the manuscript and approval of the final version for publication.

\section{RESUMO}

OBJETIVO: Traçar o perfil de pacientes atendidos em uma Unidade de Terapia Intensiva Neonatal cirúrgica nível III desvinculada de maternidade e analisar fatores de risco para mortalidade nesta população.

MÉTODOS: estudo de coorte retrospectivo, avaliando os pacientes internados em um serviço de Unidade de Terapia Intensiva Neonatal cirúrgica nível III de referência no estado no período de junho/2015 a novembro/2017. A análise univariada foi realizada pelo teste de Quiquadrado e T-student ou Mann-Whitney. Foi realizada a analise multivariada por regressão logística incluindo no modelo as variáveis que apresentaram valor de $P<0,2$ na analise univariada. Foi realizada curva de Kaplan-Meier e teste Log-Rank com as varáveis que foram estatisticamente associadas ao óbito na análise multivariada. Adotou-se um nível de significância de a=5\% e um erro B=80\%.

RESULTADOS: Neste período, 246 pacientes foram internados neste serviço. Foram a óbito 58 (23,8\%) pacientes, com tempo médio de óbito de 18 dias. Metade dos pacientes apresentaram diagnóstico clínico de sepse (50,6\%), com hemocultura foi positiva em 25,2\% e bactérias gram-positivas (48,4\%) foram os principais patógenos isolados. As variáveis que se mantiveram no modelo final após a análise multivariada foram diagnóstico de cardiopatia congênita $(O R=4,5 ; p=0,016)$, diagnóstico clinico de sepse $(O R=8,1 ; p=0,000)$, e isolamento de bactéria gram-positiva na hemocultura $(O R=3,9 ; p=0,006)$.

CONCLUSÃo: O serviço de Unidade de Terapia Intensiva cirúrgica nível III não vinculada a maternidade apresenta perfil diferenciado de morbimortalidade, e o óbito esteve associado ao diagnóstico de cardiopatia congênita, ao diagnostico clinico de sepse e ao isolamento de bactérias gram-positivas na hemocultura.

PALAVRAS-CHAVE: Mortalidade infantil. Anormalidades congênitas/cirurgia. Unidades de terapia intensiva neonatal.

\section{REFERENCES}

1. Brasil. Ministério da Saúde. Saúde Brasil 2014: uma análise da situação de saúde e das causas externas. Brasília: Ministério da Saúde; 2015. [cited 2019 Nov 11]. Available from: https://bvsms.saude.gov.br/bvs/publicacoes/ saude_brasil_2014_analise_situacao.pdf

2. Richardson DK, Gray JE, Gortmaker SL, Goldmann DA, Pursley DM, McCormick MC. Declining severity adjusted mortality: evidence of improving neonatal intensive care. Pediatrics. 1998;102(4 Pt 1):893-9.

3. Corsello G, Giuffrè M. Congenital malformations. J Matern Fetal Neonatal Med. 2012;25(Suppl 1):25-9.

4. Drumond EF, Machado C), França E. Óbitos neonatais precoces: análise de causas múltiplas de morte pelo método Grade of Membership. Cad Saúde Pública. 2007;23(1):157-66.

5. Associação de Medicina Intensiva Brasileira. Censo AMIB 2016. São Paulo: Associação de Medicina Intensiva Brasileira; 2016. [cited 2019 Nov 11]. Available from: www.amib.org.br/censo-amib/censo-amib-2016/

6. Souza DC, Troster E), Carvalho WB, Shin SH, Cordeiro AM. Availability of pediatric and neonatal intensive care units in the city of São Paulo. I Pediatr (Rio J). 2004;80(6):453-60.

7. Lansky S, Friche AAL, Silva AAM, Campos D, Bittencourt SDA, Carvalho $\mathrm{ML}$, et al. Pesquisa Nascer no Brasil: perfil da mortalidade neonatal e avaliação da assistência à gestante e ao recém-nascido. Cad Saúde Pública. 2014;30(suppl.1):S192-S207.

8. Araújo BF, Tanaka AC d' A, Madi JM, Zatti H. Estudo da mortalidade de recém-nascidos internados na UTI neonatal do Hospital Geral de Caxias do Sul, Rio Grande do Sul. Rev Bras Saúde Mater Infant. 2005;5(4):463-9.
9. Menezes $A M B$, Victora CG, Barros FC, Albernaz E, Menezes FS, Jannke $\mathrm{HA}$, et al. Mortalidade infantil em duas coortes de base populacional no Sul do Brasil: tendências e diferenciais. Cad Saúde Pública. 1996;12(suppl 1):S79-86.

10. Stewart DL, Hersh JH. The impact of major congenital malformations on mortality in a neonatal intensive care unit. I Ky Med Assoc. 1995;93(8):329-32.

11. Hoffman Jl, Kaplan S. The incidence of congenital heart disease. J Am Coll Cardiol. 2002;39(12):1890-900.

12. Nascimento LFC. Fatores de risco para óbito em Unidade de Terapia Intensiva Neonatal. Rev Paul Pediatr. 2009;27(2):186-92.

13. Connell TG, Rele M, Cowley D, Buttery JP, Curtis N. How reliable is a negative blood culture result? Volume of blood submitted for culture in routine practice in a children's hospital. Pediatrics. 2007;119(5):891-6.

14. Mussi-Pinhata MM, Nascimento SD. Neonatal nosocomial infections. Pediatr (Rio J). 2001;77(suppl. 1):S81-96.

15. Gaynes RP, Edwards |R, Jarvis WR, Culver DH, Tolson IS, Martone W| Nosocomial infections among neonates in high-risk nurseries in the United States. National Nosocomial Infections Surveillance System. Pediatrics. 1996;98(3 Pt 1):357-61.

16. Marchant EA, Boyce GK, Sadarangani M, Lavoie PM. Neonatal sepsis due to coagulase-negative Staphylococci. Clin Dev Immunol. 2013;2013:586076. 